\title{
Low-Temperature Formation of $\alpha$-Alumina from Polyhydroxoaluminum-Lactic Acid Composite Gels
}

\author{
Masahiro HIDA, Tomohiro YAMAGUCHI, Takayuki FUJITA, ${ }^{*}$ Seiichi TARUTA and Kunio KITAJIMA \\ Department of Chemistry and Material Engineering, Faculty of Engineering, Shinshu University, 4-17-1, Wakasato, Nagano-shi 380-8553 \\ *Taimei Chemicals Co., Ltd., 4150, Minamiminowa-mura, Kamiina-gun, Nagano 399-4597
}

\author{
多核ヒドロキソ Al-乳酸系複合ゲルからの $\alpha$-アルミナの低温析出 \\ 飛田将大 ·山口朋浩 $\cdot$ 藤田隆之 $*$ 樽田誠一 ·北島图夫 \\ 信州大学工学部物質工学科, 380-8553 長野県長野市若里 4-17-1 \\ *大明化学工業(株), 399-4597 長野県上伊那郡南箕輪村 4150
}

\begin{abstract}
Polyhydroxoaluminum (PHA)-lactic acid (LA) composite gels were prepared from PHA-LA mixed solutions. Phase transition behavior of the composite gels under heat-treatment was studied. The gels transformed into transition aluminas and/or $\alpha$-alumina, depending on the heat-treatment conditions. Composite gels containing 3-10 mass $\%$ LA were found to yield $\alpha$-alumina when heat-treated at low temperatures of around $500^{\circ} \mathrm{C}$. The low-temperature formation of $\alpha$-alumina was promoted at low heating rates. The fraction of $\alpha$-alumina formed in the heat-treated products increased with temperature, reaching 40 mass $\%$ at $\sim 800^{\circ} \mathrm{C}$. The low-temperature formation of $\alpha$-alumina is induced by the transformation of a partially formed diaspore-like structure, which is enhanced with reducing heating rate. The formation of 6-coordinated Al from 4-coordinated Al via the intermediate 5-coordinated Al during heat-treatment seems to be key to the formation of the diaspore-like structure, leading to the low-temperature formation of $\alpha$-alumina.
\end{abstract}

[Received August 26, 2004; Accepted December 15, 2004]

Key-words : $\alpha$-alumina, Low-temperature formation, Sol-gel method, Polyhydroxoaluminum solution, Lactic acid

\section{Introduction}

Alpha-alumina (corundum), which is a thermodynamically stable polymorph, is widely used in applications including high-strength materials, electronics and catalytic supports. Recently, due to interest in anisotropically shaped oxide ceramic powders for metal-ceramic composites and polymer matrix composites, the synthesis of $\alpha$-alumina powders having controlled shape and size tailored to a specific application has attracted much attention. ${ }^{1,2)}$

In general, $\alpha$-alumina is produced by the calcination of various alumina precursors, including aluminum hydroxides such as bayerite, gibbsite and boehmite, and aluminum salts such as sulfate, nitrate, chloride and organic acid salts. Typically, the precursors first transform into metastable transition aluminas such as $\delta$-, $\gamma$-, $\eta$-, $\theta-, \kappa$ - and $\chi$-phase aluminas, depending on the starting species, temperature and ambient atmosphere. The transition aluminas then transform into $\alpha$-alumina upon further heating, and thus $\alpha$-alumina is difficult to synthesize at temperatures below $1100^{\circ} \mathrm{C}$. It is difficult to obtain $\alpha$-alumina having fine primary particles because of the sintering at such high temperatures. ${ }^{3), 4)}$ To prevent particle growth, the low-temperature formation of $\alpha$-alumina has also been attempted using various methods, such as sol-gel, ${ }^{5)-13)}$ solution, ${ }^{14)-17)}$ vapor-phase, ${ }^{18)}$ mechani$\mathrm{cal} /$ thermal routes $^{19), 20)}$ and the introduction of seeds. ${ }^{4), 21)-23 \text { ) }}$ However, most of these approaches still require temperatures above $800^{\circ} \mathrm{C}$ to form $\alpha$-alumina.

Diaspore $(\alpha$-AlOOH $)$ dehydrates to form $\alpha$-alumina directly at $\sim 450^{\circ} \mathrm{C}^{24)}$ This unique transformation is attributable to the structural similarities between diaspore and corundum; both have a hexagonal close-packed anion sublattice. However, natural high-purity diaspore occurs in limited quantities in nature, and its synthesis requires severe hydrothermal conditions $\left(\sim 300^{\circ} \mathrm{C},>30 \mathrm{MPa}\right)$. Diaspore-like precursors, which also transform into $\alpha$-alumina at temperatures as low as $450^{\circ} \mathrm{C}$, have been synthesized under moderate conditions. ${ }^{5)-12)}$ Brand and co-workers ${ }^{5)-8)}$ obtained a mixture of $\alpha$-alumina ( $\sim 40$ mass $\%)$ and amorphous phase by the heat-treating of precursors prepared from the $\mathrm{Al}-\mathrm{O}-\mathrm{H}-\mathrm{Cl}$ system at 500$800^{\circ} \mathrm{C}$ under a rapid flow $(\sim 500 \mathrm{~L} / \mathrm{h})$ of air or nitrogen. Kamiya et al. ${ }^{9)}$ synthesized precursors by the sol-gel method using aluminum sec-butoxide. The precursors transformed into $\alpha$-alumina in static air at $500^{\circ} \mathrm{C}$ or below, and the fraction of $\alpha$-alumina was $\sim 30$ mass $\%$ at $600^{\circ} \mathrm{C}$. They assumed that the diaspore-like structure was partially built during the solgel reaction. Kamiya et al. also reported the effects of seeding the gel with corundum particles; the fraction of $\alpha$-alumina formed from the seeded gel at $600^{\circ} \mathrm{C}$ was 40 mass $\%$ or more. ${ }^{10)}$ Smith et al. ${ }^{12)}$ examined the effects of diaspore-seeding on the crystallization of gels prepared from aluminum secbutoxide and reported a complete transformation to $\alpha$-alumina at $700^{\circ} \mathrm{C}$ by 4.1 mass\% seeding.

Concentrated polyhydroxoaluminum (hereafter PHA) solutions prepared by the $\mathrm{Al}$ metal dissolution method have such features as a high $\mathrm{OH} / \mathrm{Al}$ ratio and a high content of the highly polymerized Keggin $\mathrm{Al}_{13}$ ion $\left(\left[\mathrm{Al}_{13} \mathrm{O}_{4}(\mathrm{OH})_{12}\left(\mathrm{H}_{2} \mathrm{O}\right)_{24}\right]^{7+}\right)$ species. ${ }^{25)}$ PHA gels obtained by drying PHA solutions can be transformed into transition aluminas by heat-treatment. ${ }^{26)}$ The preparation of transition aluminas with controlled polymorph and pore properties has been attempted by using PHA composite gels containing organic additives such as polyethylene glycol and quaternary ammonium ions. ${ }^{27)-31)}$ The interaction of additives with PHA ions to modulate the gel structure was key in controlling the polymorph and pore properties.

In the present study, lactic acid (hereafter LA) was used as an additive for the preparation of PHA composite gels as alu- 
mina precursors. The small LA molecule contains both $-\mathrm{OH}$ and $-\mathrm{COOH}$ groups. The addition of LA may modulate the PHA gel structure through the interaction of $\mathrm{OH}$ groups in PHA ions with the functional groups of LA. The phase transition of the PHA-LA composite gels was investigated. We found that part of the composite gels transformed into $\alpha$-alumina at low temperatures of around $500^{\circ} \mathrm{C}$. Thus, the aims of this study were (1) to clarify the effects of LA content on the thermal transformation of PHA-LA composite gels and (2) to investigate the effects of heat-treatment conditions on the low-temperature formation of $\alpha$-alumina from PHA-LA composite gels. The results revealed that the low-temperature formation of $\alpha$-alumina occurred only when the LA content and the heat-treatment conditions were optimized.

\section{Experimental}

A PHA solution containing 23.4 mass $\% \mathrm{Al}_{2} \mathrm{O}_{3}$ and having an $\mathrm{OH} / \mathrm{Al}$ ratio of 2.51 was prepared by dissolving $\mathrm{Al}$ metal in an $\mathrm{HCl}$ solution, as previously described. ${ }^{25)}$ LA (Wako Pure Chemical Industries) was added to this starting solution and stirred for 30 min to prepare the PHA-LA mixed solutions. The amount of LA was varied from 0 to 50 mass $\%$, based on the mass of $\mathrm{Al}_{2} \mathrm{O}_{3}$ obtained from the PHA solution. The PHA-LA mixtures were then held at $60^{\circ} \mathrm{C}$ for $2 \mathrm{~d}$ to prepare the PHA-LA composite gels.

The PHA-LA composite gels were heat-treated at 400$1000^{\circ} \mathrm{C}$ for $3 \mathrm{~h}$ in air, and were brought to the heat-treatment temperature at a heating rate of $1.5^{\circ} \mathrm{C} / \mathrm{min}$. Heating rates of $1.0,3.0$ and $5.0^{\circ} \mathrm{C} / \mathrm{min}$ were also used. The composite gels and their heat-treated products were ground using an agate mortar and pestle, and passed through a 325 mesh $(45 \mu \mathrm{m})$ sieve prior to characterization.

Powder XRD patterns of the composite gels and their heattreated products were recorded using $\mathrm{Cu} \mathrm{K} \alpha$ radiation with a monochromator. The mass fraction of $\alpha$-alumina in the heattreated products was estimated from the relative intensity of the (104) reflection of $\alpha$-alumina with respect to the (111) reflection of $\mathrm{CaF}_{2}$ added as an internal standard. The FT-IR spectra of the samples were obtained by means of the $\mathrm{KBr}$ tablet method using a spectrometer in the range of 4000-450 $\mathrm{cm}^{-1} .{ }^{27} \mathrm{Al}-\mathrm{MAS}$ NMR spectra were recorded using a spectrometer at $78.2287 \mathrm{MHz}$ with an MAS frequency of 10.3 $\mathrm{kHz}$. The standard for the ${ }^{27} \mathrm{Al}$ chemical shifts was an aqueous solution of $\mathrm{Al}_{2}\left(\mathrm{SO}_{4}\right)_{3}$. The morphology of the heat-treated products was observed by means of SEM.

\section{Results and discussion}

\subsection{PHA-LA composite gels}

Figure 1 shows XRD patterns of PHA-LA composite gels of varying LA content. The PHA gel and PHA-LA composite gels had a broad reflection peak at approximately $2 \theta=8^{\circ}(\mathrm{Cu}$ $\mathrm{K} \alpha$ ), ascribable to a loosely stacked structure consisting of highly polymerized PHA ions. The diffraction angle of the peak shifted slightly to the lower angle side when the LA content of the PHA-LA composite gels was increased up to 40 mass\%, while additives such as polyethylene glycol and quaternary ammonium ions modulated the composite gel structure so that the peak at approximately $2 \theta=8^{\circ}$ shifted clearly to lower angles with increasing the additive amount. ${ }^{27), 30), 31)}$ In addition, the halo pattern, which appeared around $20-35^{\circ}$, was slightly changed in shape with the addition of LA. These suggest that LA has a slight effect on the modulation of the loosely stacked structure observed in the composite gels.

Figure 2 shows the IR spectra of typical PHA-LA compo-

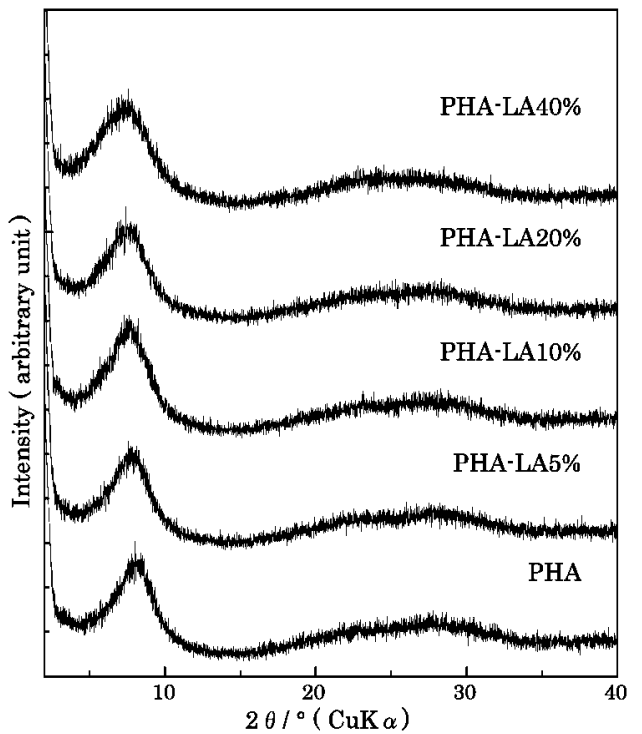

Fig. 1. XRD patterns of PHA and PHA-LA composite gels of varying LA contents.

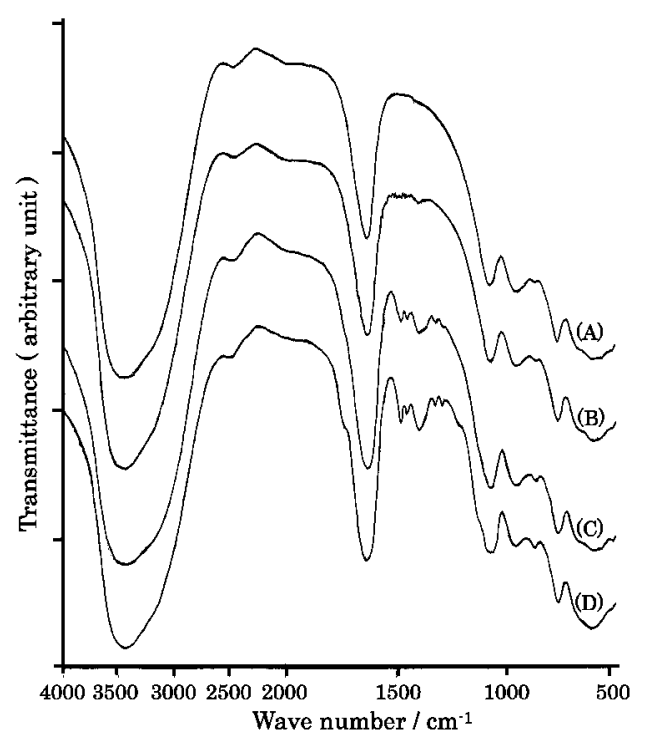

Fig. 2. IR spectra of PHA and PHA-LA composite gels of varying LA contents. (A) PHA, (B) PHA-LA5\%, (C) PHA-LA20\%, (D) PHA-LA40\%.

site gels. Absorption bands assignable to the $\mathrm{OH}$ stretching and bending modes of $\mathrm{H}_{2} \mathrm{O}$ were observed around $3400 \mathrm{~cm}^{-1}$ and $1600 \mathrm{~cm}^{-1}$, respectively. Absorption bands resulting from LA appeared at $1500-1350 \mathrm{~cm}^{-1}$ and increased in intensity as the LA content of the gels was increased. Absorption bands related to $\mathrm{Al}-\mathrm{O}$ bonds appeared below $1200 \mathrm{~cm}^{-1}$. The absorption bands at 1090 and $970 \mathrm{~cm}^{-1}$ are assignable to the Al-O-H bending mode. ${ }^{6)}$ The band at $790 \mathrm{~cm}^{-1}$ is assignable to $\mathrm{AlO}_{4}$ stretching, while that at $620 \mathrm{~cm}^{-1}$ and the shoulder at $550 \mathrm{~cm}^{-1}$ are attributable to the $\mathrm{AlO}_{6}$ stretching mode. The wave number and intensity of such absorption bands below $1200 \mathrm{~cm}^{-1}$ were almost unaffected by differences in LA content, except for the band at around $900 \mathrm{~cm}^{-1}$. Therefore, the addition of LA appears to lead to only a slight change in the local structure of the composite gels. These XRD and IR studies show that the LA present in the composite gels has some 


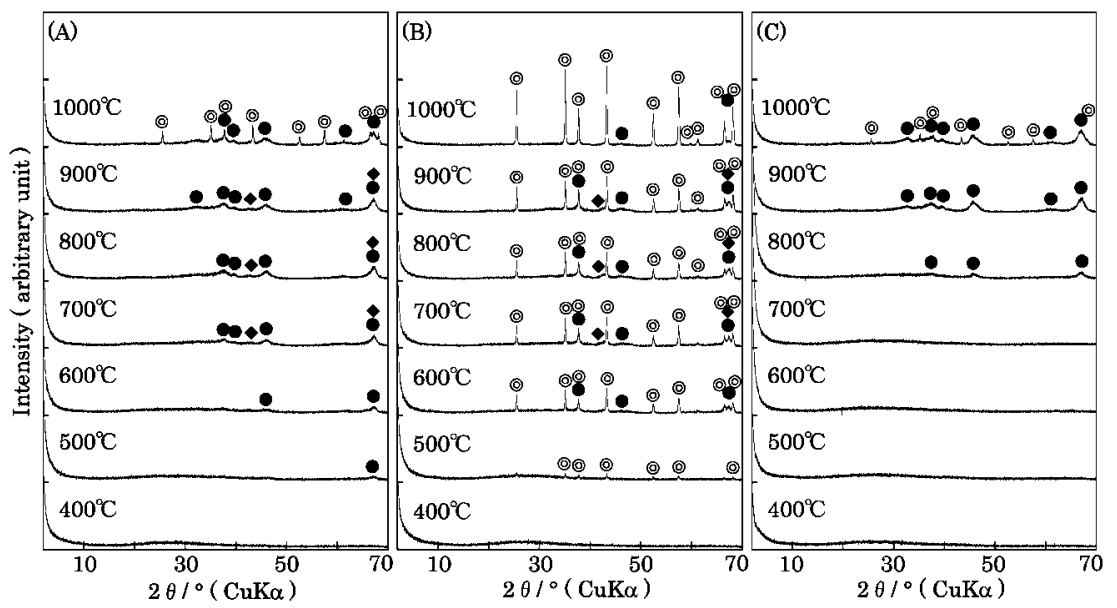

Fig. 3. XRD patterns of products obtained by heating (A) PHA, (B) PHA-LA5\% and (C) PHA-LA20\% composite gels at different temperatures for $3 \mathrm{~h}$. $\gamma$-alumina, $\chi$-alumina, () $\alpha$-alumina.

effect on the modulation of the PHA gel structure or the fluctuation of the coordination number of $\mathrm{Al}$ ions.

\subsection{Thermal decomposition of PHA-LA composite gels}

Figure 3 shows the XRD patterns of the products obtained by heating PHA-LA composite gels at $400-1000^{\circ} \mathrm{C}$ for $3 \mathrm{~h}$ (heating rate to target temperature: $1.5^{\circ} \mathrm{C} / \mathrm{min}$ ). Various polymorphs of alumina were crystallized from the composite gels depending on the LA content and heating temperature. In the PHA gel (Fig. 3(A)), $\gamma$-alumina formed at $500^{\circ} \mathrm{C}$, gradually increasing in amount as the heat-treatment temperature increased. A weak reflection of $\chi$-alumina with a characteristic peak at $42.5^{\circ}(\mathrm{Cu} \mathrm{K} \alpha)$ appeared above $700^{\circ} \mathrm{C}$. Transformation into $\alpha$-alumina occurred at $1000^{\circ} \mathrm{C}$. This crystallization behavior of the PHA gel matched that reported previously. ${ }^{26)}$ On the other hand, the PHA-LA5\% composite gel partially crystallized into $\alpha$-alumina at temperatures as low as $500^{\circ} \mathrm{C}$, following which transition aluminas formed from the residual amorphous phase above $600^{\circ} \mathrm{C}$ with increasing temperature (Fig. 3(B)). This unusual crystallization behavior, namely, the formation of $\alpha$-alumina at considerably low temperatures, resembles the thermal decomposition route of natural diaspore $(\alpha-\mathrm{AlOOH}){ }^{3}{ }^{324)}$ A similar phenomenon has been reported by several researchers in the case of sol-gel-derived precursors from $\mathrm{AlCl}_{3} \cdot 6 \mathrm{H}_{2} \mathrm{O}$ or aluminum alkoxide as a starting material. ${ }^{5)-12)}$ In the present work, a small amount of LA (3-10 mass \%) was all that was required for the low-temperature formation of $\alpha$-alumina to occur. The peaks assignable to $\alpha$-alumina became sharper at $1000^{\circ} \mathrm{C}$, accompanied by a rapid decrease in the intensity of the peaks assignable to transition aluminas and also by the disappearance of the halo at $20^{\circ}$ $40^{\circ}$. In contrast to composite gels containing $\leq 10$ mass $\%$ LA, PHA-LA20\% gels retained their amorphous state up to $700^{\circ} \mathrm{C}$ and transformed into $\gamma$-alumina above $800^{\circ} \mathrm{C}$ (Fig. 3(C)). A small amount of $\alpha$-alumina was formed by heating the PHA-LA20\% composite gel at $1000^{\circ} \mathrm{C}$, due to the transformation of $\gamma$-alumina. The transformation behavior of composite gels containing $>20$ mass\% LA was almost the same as that of the PHA-LA20\% composite gel. This suggests that the addition of LA to PHA solution is effective for controlling the polymorph of the resultant aluminas, in particular, for producing $\alpha$-alumina at low temperatures.

Figure 4 shows the mass fraction of $\alpha$-alumina obtained at different temperatures. As mentioned above, $\alpha$-alumina was crystallized from PHA-LA composite gels containing 3-10

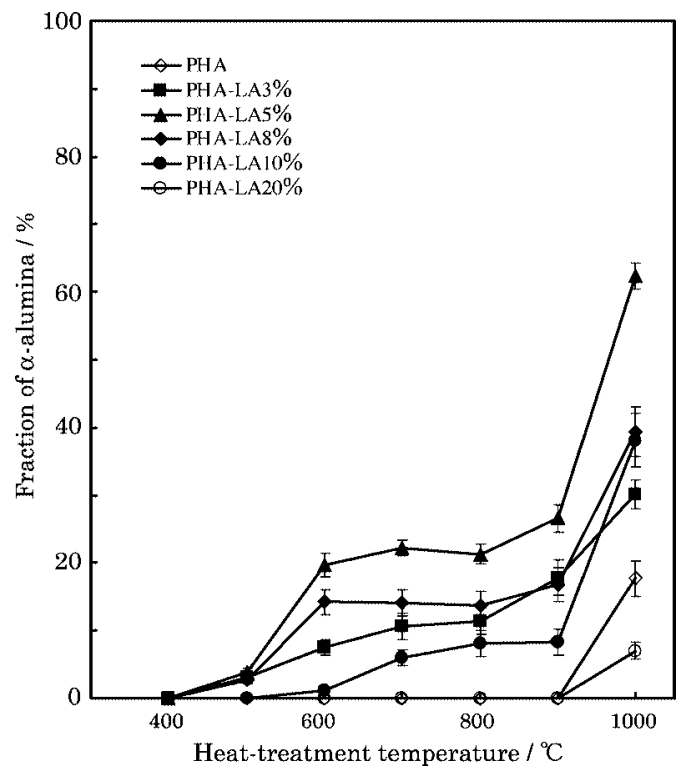

Fig. 4. Fractions of $\alpha$-alumina formed from PHA and PHA-LA composite gels of varying LA contents vs. heat-treatment temperature. Heating rate: $1.5^{\circ} \mathrm{C} / \mathrm{min}$.

mass $\% \mathrm{LA}$ at around $500^{\circ} \mathrm{C}$. The fraction of $\alpha$-alumina increased with LA content up to 5 mass $\%$ and then decreased with further increase in LA content $(\geq 8$ mass\%). On the basis of these results, PHA-LA5\% is judged to be the best precursor under the present conditions, with respect to the low-temperature formation of $\alpha$-alumina.

LA molecules in composite gels with low LA contents interact with PHA ions through their functional groups, combining the clustered domains of PHA ions. However, the addition of excessive amounts of LA leads to the isolation of these clustered domains, allowing the formation of a continuous LA matrix. The counterbalance between these two effects may explain why the PHA-LA5\% composite gel yields the maximal $\alpha$-alumina fraction.

Diaspore, one of the polymorphs of $\mathrm{AlOOH}$, transforms into $\alpha$-alumina at low temperatures $\left(450^{\circ} \mathrm{C}\right) .^{24)}$ Kamiya and co-workers ${ }^{9), 10)}$ reported that alumina gels prepared under carefully controlled conditions transformed into $\alpha$-alumina at 
$500^{\circ} \mathrm{C}$ or lower, and concluded that direct transformation into $\alpha$-alumina at such low temperatures was probably caused by the partial formation of a diaspore-like structure during the sol-gel process. ${ }^{9)}$ Hence, it is plausible that a similar process occurs in the PHA-LA system during the heat-treatment process.

The mass fraction of $\alpha$-alumina increased in two steps: in the low-temperature range of 500 to $600^{\circ} \mathrm{C}$ and the high-temperature range of 900 to $1000^{\circ} \mathrm{C}$. A similar stepwise increase in $\alpha$-alumina fraction was reported by Kamiya and co-workers. ${ }^{9,10)}$ The first increase in the $\alpha$-alumina fraction results from the low-temperature formation of $\alpha$-alumina directly from the precursor gels; the second is due to the transformation from transition aluminas, where the low-temperature $\alpha$ alumina acts as a seed. In addition, residual amorphous alumina also may contribute to the second increase through the intermediate formation of transition alumina. The fraction of $\alpha$ alumina remained almost constant between 700 and $900^{\circ} \mathrm{C}$. This shows that the addition of LA (3-10 mass\%) affects the crystallization of $\alpha$-alumina, principally below $700^{\circ} \mathrm{C}$.

3.3 Effects of heat-treatment conditions on the formation of $\alpha$-alumina at low temperatures

To determine the effect of heating rate on the low-temperature formation of $\alpha$-alumina, the PHA-LA5\% composite gel was heat-treated under different heating rates. Figure 5 shows the XRD patterns. The formation of $\alpha$-alumina was promoted by heating at $1.0^{\circ} \mathrm{C} / \mathrm{min}$, to a greater extent than at $1.5^{\circ} \mathrm{C} / \mathrm{min}$ (refer to Fig. 3(B)). In the case of products obtained at faster heating rates $\left(\geq 3.0^{\circ} \mathrm{C} / \mathrm{min}\right), \alpha$-alumina was not crystallized in the low-temperature range $\left(\sim 500^{\circ} \mathrm{C}\right)$, but was rather formed at $1000^{\circ} \mathrm{C}$ by the transformation of the transition aluminas. Figure 6 shows the $\alpha$-alumina fraction of the products as a function of the heat-treatment temperature. Clearly, the fraction of $\alpha$-alumina obtained from the PHA-LA5\% composite gel increased as the heating rate was reduced. This shows that $\alpha$-alumina forms at a low temperature (i.e., at $500^{\circ} \mathrm{C}$ ) only when the LA-poor gels (3-10 mass\% LA) are heat-treated under low heating rates.

Low heating rates promote the formation of the diasporelike structure because the time spent at its formation temperature is prolonged. Thus, the larger the diaspore-like region, the higher the amount of resultant low-temperature $\alpha$-alumina. The fraction of $\alpha$-alumina remained almost constant between 700 and $900^{\circ} \mathrm{C}$ regardless of the heating rate, as shown in Fig. 6. This means that the heat-treatment in this temperature range may not directly contribute to the formation of $\alpha$ alumina. Thus, the formation of the diaspore-like region presumably occurs below $600^{\circ} \mathrm{C}$.

The $\alpha$-alumina fractions at $600-900^{\circ} \mathrm{C}$ in the present study ranged between 10 and 40 mass $\%$, depending on the LA content and heating rate. Brand and co-workers ${ }^{5)-8)}$ achieved $\sim 40$ mass $\% \alpha$-alumina at $\sim 800^{\circ} \mathrm{C}$ from the $\mathrm{Al}-\mathrm{O}-\mathrm{H}-\mathrm{Cl}$ system using the precursors obtained from $\mathrm{AlCl}_{3} \cdot 6 \mathrm{H}_{2} \mathrm{O}$. Kamiya and co-workers ${ }^{9), 10)}$ reported $\sim 20$ and $40 \% \alpha$-alumina fractions from aluminum sec-butoxide-derived precursors without and with corundum-seeding, respectively, although the precursors and heat-treatment conditions differed from those of the present study. The difference in the fraction of low-temperature $\alpha$-alumina may partly result from the ability to form the diaspore-like region in the precursors. Although the formation mechanism of the diaspore-like structure in the present composite gels is a problem that remains to be solved, the further enhancement of the low-temperature $\alpha$-alumina fraction can be expected by increasing the diaspore-like structure in the composite gels through the improvement of the sol-gel and

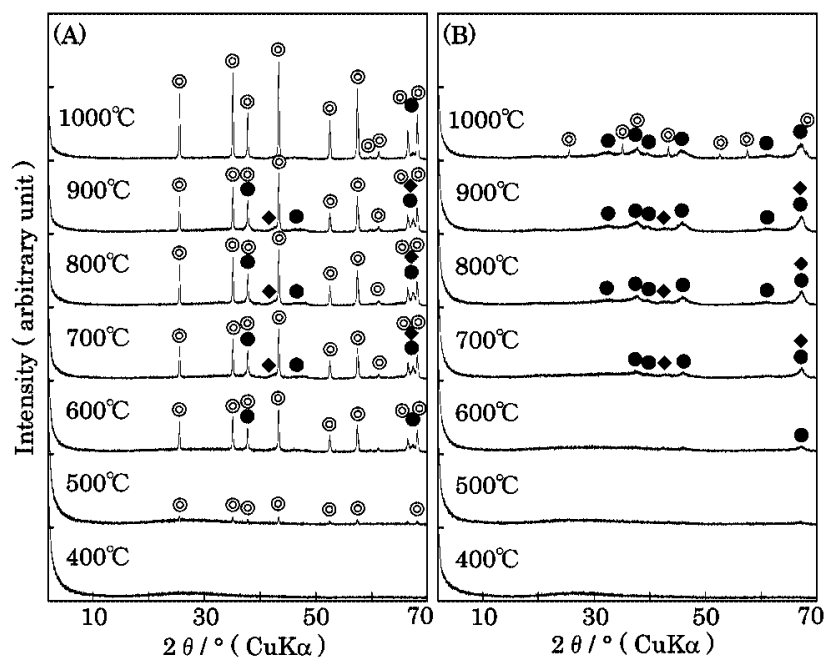

Fig. 5. XRD patterns of products obtained by heating PHA-LA5\% gels at different temperatures for $3 \mathrm{~h}$. Heating rate: (A) $1.0^{\circ} \mathrm{C} / \mathrm{min}$, (B) $3.0^{\circ} \mathrm{C} / \mathrm{min}$. $\gamma$-alumina, $\downarrow$-alumina, (C) $\alpha$-alumina.

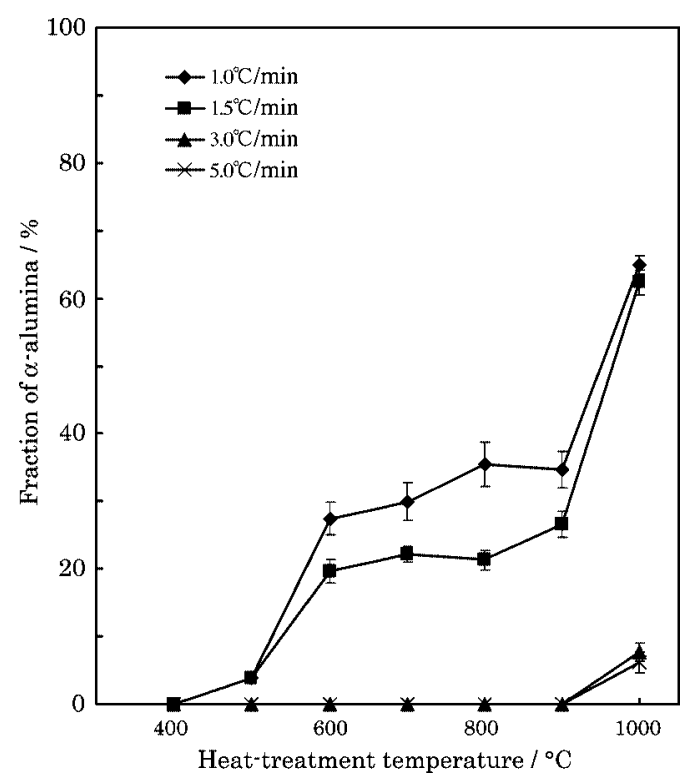

Fig. 6. Fractions of $\alpha$-alumina formed from the PHA-LA5\% gel vs. heat-treatment temperature under different heating rates.

heat-treatment process.

3.4 NMR study and SEM observation of the products

To elucidate the formation mechanism of the low-temperature $\alpha$-alumina, the coordination number of $\mathrm{Al}$ in the products obtained by heating the PHA-LA composite gels under the heating rate of $1.0^{\circ} \mathrm{C} / \mathrm{min}$ at $500^{\circ} \mathrm{C}$ for $30 \mathrm{~min}$ was measured by means of ${ }^{27} \mathrm{Al}-\mathrm{MAS}$ NMR spectroscopy. Figure 7 shows the NMR spectra. All the samples gave peaks at around 65 ppm and $5 \mathrm{ppm}$, which were assignable to 4-coordinated $\mathrm{Al}$ $\left(\mathrm{Al}^{\mathrm{IV}}\right)$ and 6-coordinated $\mathrm{Al}\left(\mathrm{Al}^{\mathrm{VI}}\right)$, respectively. ${ }^{6}$ ) Between these peaks, a peak assignable to 5-coordinated $\mathrm{Al}\left(\mathrm{Al}^{\mathrm{V}}\right)^{,}$, whose intensity depended on the LA content, appeared at around $35 \mathrm{ppm}$. The heat-treatment products from the PHA gel gave an $\mathrm{Al}^{\mathrm{IV}}$ peak and a weak $\mathrm{Al}^{\mathrm{V}}$ peak. The intensity of the $\mathrm{Al}^{\mathrm{V}}$ peak increased with the addition of LA, most markedly in the case of PHA-LA5\%. As with $\alpha$-alumina, the diaspore is composed of only $\mathrm{Al}^{\mathrm{VI}}$. $\mathrm{Al}^{\mathrm{V}}$ changes easily into $\mathrm{Al}^{\mathrm{VI}}$ by 

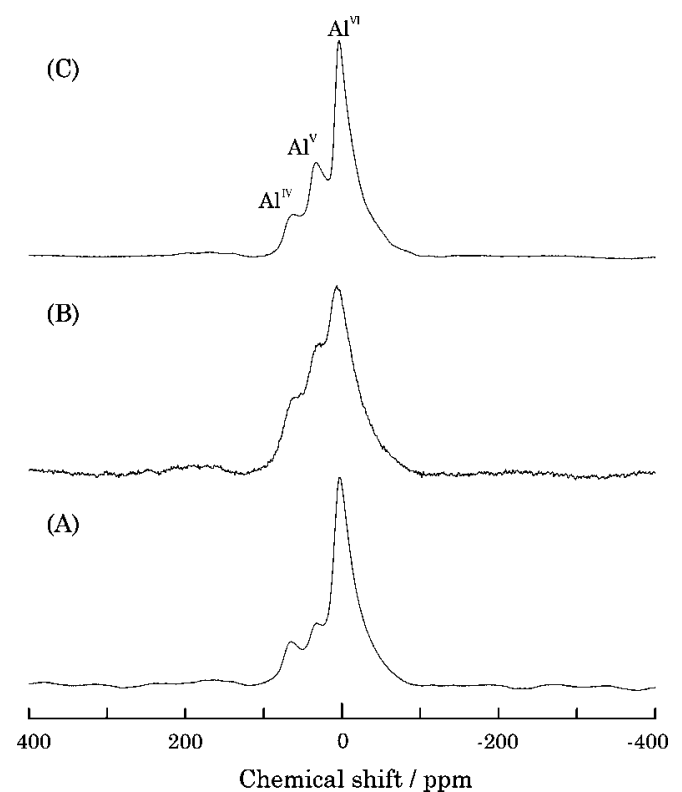

Fig. 7. ${ }^{27}$ Al-MAS NMR spectra of products obtained from (A) PHA, (B) PHA-LA5\% and (C) PHA-LA20\% composite gels by heating at $500^{\circ} \mathrm{C}$ for $30 \mathrm{~min}$. Heating rate: $1.0^{\circ} \mathrm{C} / \mathrm{min}$.
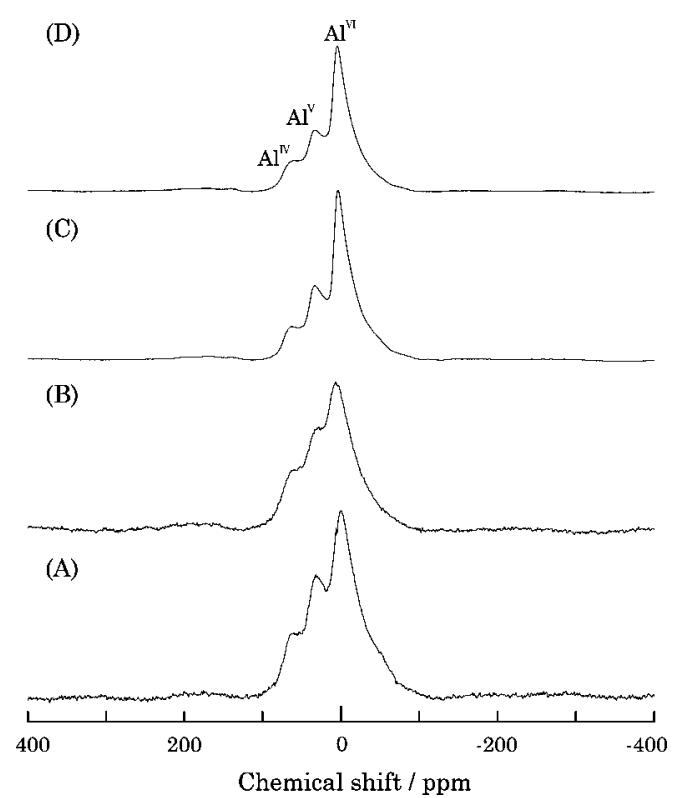

Fig. 8. ${ }^{27} \mathrm{Al}-\mathrm{MAS}$ NMR spectra of products obtained from PHALA composite gels heat-treated at different temperatures for $30 \mathrm{~min}$. (A) PHA-LA5 $\%$ at $450^{\circ} \mathrm{C}$, (B) PHA-LA5\% at $500^{\circ} \mathrm{C}$, (C) PHA$\mathrm{LA} 20 \%$ at $500^{\circ} \mathrm{C}$ and (D) PHA-LA20\% at $700^{\circ} \mathrm{C}$. Heating rate: $1.0^{\circ} \mathrm{C} / \mathrm{min}$.

a small shift and insertion of a supplemental anion. ${ }^{6)}$ Thus, the formation of the $\mathrm{Al}^{\mathrm{V}}$ from the PHA-LA composite gels at $\leq 500^{\circ} \mathrm{C}$ seems to be key to the formation of the diaspore-like structure, and hence, the crystallization of $\alpha$-alumina at low temperatures.

Figure 8 shows the ${ }^{27} \mathrm{Al}-\mathrm{MAS}$ NMR spectra of the products obtained by heating PHA-LA5\% and 20\% at different temperatures for $30 \mathrm{~min}$. The sample obtained from PHA-LA5\% exhibited a relatively strong $\mathrm{Al}^{\mathrm{V}}$ peak at $450^{\circ} \mathrm{C}$. The $\mathrm{Al}^{\mathrm{V}}$ peak weakened upon further heating at $500^{\circ} \mathrm{C}$. Brand et al. ${ }^{6}{ }^{\text {r }}$ report-
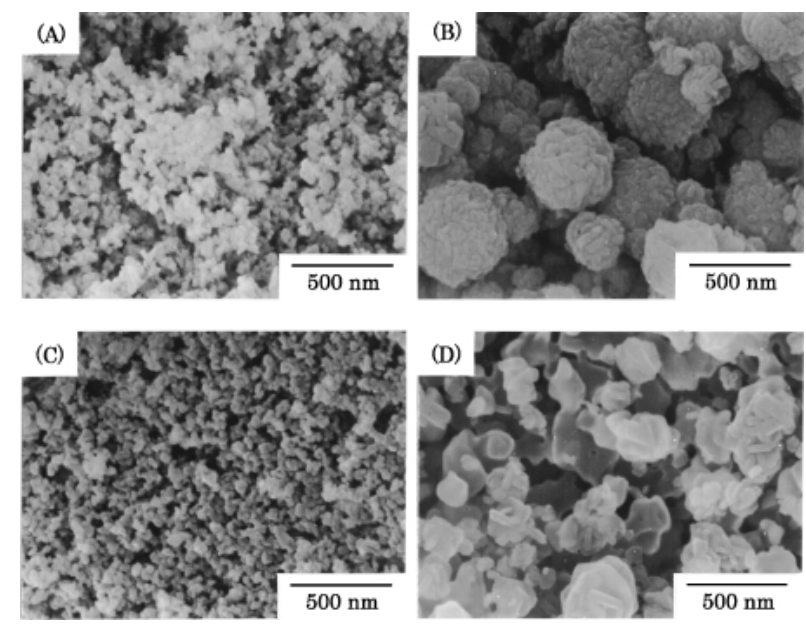

Fig. 9. SEM photographs of products obtained by heating the PHA-LA5\% composite gel at $800^{\circ} \mathrm{C}((\mathrm{A})$ and $(\mathrm{B}))$ and $1000^{\circ} \mathrm{C}((\mathrm{C})$ and $(D))$ for $3 \mathrm{~h}$. Heating rate: $1.5^{\circ} \mathrm{C} / \mathrm{min}$.

ed the formation of $\mathrm{Al}^{\mathrm{V}}$ in the product obtained by heating a $\mathrm{AlCl}_{3} \cdot 6 \mathrm{H}_{2} \mathrm{O}$-derived gel at $300^{\circ} \mathrm{C}$ and the subsequent change into $\mathrm{Al}^{\mathrm{VI}}$ at $550^{\circ} \mathrm{C}$, accompanied by the decrease in intensity of the $\mathrm{Al}^{\mathrm{IV}}$ and $\mathrm{Al}^{\mathrm{V}}$ peaks. The $\mathrm{Al}^{\mathrm{V}}$ observed at $450-500^{\circ} \mathrm{C}$ in the present study is an intermediate configuration in the coordination change from $\mathrm{Al}^{\mathrm{IV}}$ to $\mathrm{Al}^{\mathrm{VI}}$. The $\mathrm{Al}^{\mathrm{V}}$ formed in the amorphous products is most likely to change into $\mathrm{Al}^{\mathrm{VI}}$ during heattreatment. $\mathrm{Al}^{\mathrm{VI}}$ may be partly related to the formation of the diaspore-like structure, resulting in the crystallization of $\alpha$ alumina at low temperatures. Unlike the PHA-LA5\% composite gel, the $\mathrm{Al}^{\mathrm{V}}$ peak in the PHA-LA20\% sample persisted even after heat-treatment at $700^{\circ} \mathrm{C}$. Thus, the addition of a large amount of $\mathrm{LA}$ also led to the formation of $\mathrm{Al}^{\mathrm{V}}$ below $500^{\circ} \mathrm{C}$, but the $\mathrm{Al}^{\mathrm{V}}$ in the system was sufficiently stable to suppress crystallization even at $700^{\circ} \mathrm{C}$, plausibly because of the coexistence of thermally decomposed LA residues.

Figure 9 shows the SEM photographs of the products obtained by heating the PHA-LA5\% composite gel at different temperatures for $3 \mathrm{~h}$. The heating rate was $1.5^{\circ} \mathrm{C} / \mathrm{min}$. The heat-treatment products, which included $\alpha$-alumina transformed in the low-temperature range, exhibited a heterogeneous texture, consisting of two different morphology areas; one of fine and uniform particles (Figs. 9(A), (C)), and the other of large aggregates of plate-like crystallites less than approximately $200 \mathrm{~nm}$ in size (Figs. 9(B), (D)). The former predominated at temperatures below $\sim 800^{\circ} \mathrm{C}$, while the latter increased as the heat-treatment temperature increased and/or the heating rate reduced. These results indicate that the former fine particles correspond to transition aluminas, while the latter plate-like crystallites correspond to $\alpha$-alumina. In the case of products having a low $\alpha$-alumina fraction, $\alpha$-alumina was only partially observed in the heat-treatment products. Thus, the microstructure supports the mechanism of the low-temperature crystallization of $\alpha$-alumina from PHA-LA composite gels via partial formation of a diaspore-like region. The frequency in the appearance of the plate-like regions corresponded to the fraction of $\alpha$-alumina, and the plate-like crystallites exhibited a more clear-cut morphology at $1000^{\circ} \mathrm{C}$, retaining their dimensions of $\sim 200 \mathrm{~nm}$.

Upon heat-treating at low temperatures, the PHA-LA5\% composite gel yielded products that contained uniformly distributed mesopores $(\sim 3.4 \mathrm{~nm}$ in diameter), which is characteristic of PHA gel-derived transition aluminas. This reflects 
the texture and morphology shown in Figs. 9(A) and (C). However, the formation of $\alpha$-alumina markedly reduced the specific surface areas of the products, for example, to 24.0 and $6.4 \mathrm{~m}^{2} / \mathrm{g}$ at 800 and $1000^{\circ} \mathrm{C}$, respectively. Unlike the PHA-LA5\% composite gel, the products from composite gels containing $\geq 20$ mass $\%$ LA had a porous texture consisting of fine, uniform particles (figure not shown), giving sharp and monomodal pore size distributions at around $3.4 \mathrm{~nm}$, and had relatively large specific surface areas $\left(\sim 120 \mathrm{~m}^{2} / \mathrm{g}\right)$ at 800 $900^{\circ} \mathrm{C}$. This indicates that the addition of larger amounts of LA $(\geq 20$ mass \%) leads to the formation of uniform mesopores among $\gamma$-alumina crystallites upon heating. The formation of mesopores from composite gels containing $\geq 20$ mass\% LA probably resulted from the highly dispersed clustered domains of PHA ions in the LA matrix. Indeed, the composite gels containing larger amounts of LA gave a broader reflection with slightly larger $d$-spacing in the XRD patterns shown in Fig. 1. Thus, composite gels containing large amounts of LA are also interesting from the standpoint of ceramic processing using PHA solutions.

Recently, we reported the fabrication of alumina ceramics with high mechanical strength by pulse electric current sintering (PECS) using PHA gel-derived alumina powders consisting of transition aluminas and seeding $\alpha$-alumina. ${ }^{32)-34)}$ The $\alpha$ alumina-containing alumina powders obtained from PHALA composite gels in the current study are also promising as starting powders for PECS.

\section{Conclusion}

Low-temperature formation of $\alpha$-alumina was attempted using composite gels prepared from polyhydroxoaluminum (PHA) solution and lactic acid (LA). Effects of LA content and heat-treatment conditions on the low-temperature formation of $\alpha$-alumina were investigated. The results can be summarized as follows:

(1) PHA-LA composite gels containing 3-10 mass \% LA transformed partially into $\alpha$-alumina at around $500^{\circ} \mathrm{C}$ under heat-treatment at a heating rate of $1.5^{\circ} \mathrm{C} / \mathrm{min}$, while the PHA gel and PHA-LA composite gels containing $\geq 20$ mass $\%$ LA transformed into $\alpha$-alumina at temperatures above $1000^{\circ} \mathrm{C}$. The fraction of $\alpha$-alumina formed from the PHA-LA5\% composite gel was $\sim 25$ mass $\%$ at $600-900^{\circ} \mathrm{C}$.

(2) When the heating rate to the target temperature dropped to $1.0^{\circ} \mathrm{C} / \mathrm{min}$, the low-temperature formation of $\alpha$ alumina was promoted and the fraction of $\alpha$-alumina at $600-900^{\circ} \mathrm{C}$ reached $\sim 40$ mass $\%$. On the other hand, an increase in the heating rate prevented the direct low-temperature formation of $\alpha$-alumina. This can be explained by the partial formation of a diaspore-like structure in the composite gels during heat-treatment. Lowering of the heating rate promotes the formation of the diaspore-like structure, which can transform into $\alpha$-alumina at low temperatures, owing to the prolonged stay in the formation temperature range.

(3) ${ }^{27} \mathrm{Al}-\mathrm{MAS}$ NMR revealed that the heat-treatment products from the PHA-LA5\% composite gel contained a large amount of 5-coordinated $\mathrm{Al}$, which changes into 6-coordinated $\mathrm{Al}$ with increasing temperature. The resultant 6-coordinated $\mathrm{Al}$ seems to be key to the formation of the diasporelike region, which induces the low-temperature formation of $\alpha$-alumina in the PHA-LA system.

\section{References}

1) Sugimoto, T., Adv. Colloid. Interface Sci., Vol. 28, pp. 65-108 (1987).

2) Rajendan, M. and Bhattacharya, A. K., Mater. Lett., Vol. 39, pp. 188-195 (1999).

3 Levin, I. and Brandon, D., J. Am. Ceram. Soc., Vol. 81, pp. 1995-2012 (1998).

4) Kumagai, K. and Messing, G. L., J. Am. Ceram. Soc., Vol. 67, pp. C230-C231 (1984).

5) Brand, P., Troschke, R. and Weigelt, H., Cryst. Res. Technol., Vol. 24, pp. 671-675 (1989).

6) Brand, P., Muller, D. and Gessner, W., Cryst. Res. Technol., Vol. 25, pp. 951-956 (1990).

7) Brand, P. and Dietzmann, P., Cryst. Res. Technol., Vol. 27, pp. 529-534 (1992).

8) Brand, P., Ziegenbalg, G. and Kohnke, K., Cryst. Res. Technol., Vol. 29, pp. 179-186 (1994).

9) Kamiya, K., Yotani, J., Senba, R., Matsuoka, J. and Nasu, H., J. Ceram. Soc. Japan, Vol. 104, pp. 685-687 (1996).

10) Kamiya, K., Hioki, N., Hashimoto, T. and Nasu, H., J. SolGel Sci. Technol., Vol. 20, pp. 275-285 (2001).

11) Takeda, Y., Hashimoto, T., Nasu, H. and Kamiya, K., J. Ceram. Soc. Japan, Vol. 110, pp. 1025-1028 (2002).

12) Smith. R. L., Rohrer, G. S. and Perrotta, A. J., J. Am. Ceram. Soc., Vol. 84, pp. 1896-1902 (2001).

13) Bahlawane, N. and Watanabe, T., J. Am. Ceram. Soc., Vol. 83, pp. 2324-2326 (2000).

14) Inoue, M., Tanino, H., Kondo, Y. and Inui, T., J. Am. Ceram. Soc., Vol. 72, pp. 352-353 (1989).

15) Cho, S. B., Venigalla, S. and Adair, J. H., J. Am. Ceram. Soc., Vol. 79, pp. 88-96 (1996).

16) Sharma, P. K., Jilavi, M. H., Nass, R. and Schmidt, H., J. Am. Ceram. Soc., Vol. 81, pp. 2732-2734 (1998).

17) Das, R. N., Bandyopadhyay, A. and Base, S., J. Am. Ceram. Soc., Vol. 84, pp. 2421-2423 (2001).

18) Shaklee, C. A. and Messing, G. L., J. Am. Ceram. Soc., Vol. 77, pp. 2977-2984 (1994).

19) Tonejc, A., Stubicar, M., Tonejc, A. M., Kosanovic, K., Subotic, B. and Smit, I., J. Mater. Sci. Lett., Vol. 13, pp. 519-520 (1994).

20) Ding, J., Tsuzuki, T. and McCormick, P. G., J. Am. Ceram. Soc., Vol. 79, pp. 2956-2958 (1996).

21) Kumagai, M. and Messing, G. L., J. Am. Ceram. Soc., Vol. 68, pp. 500-505 (1985).

22) Yoshizawa, Y. and Saito, F., J. Ceram. Soc. Japan, Vol. 104, pp. 867-871 (1996) [in Japanese].

23) McArdle, J. L., Messing, G. L., Tietz, L. A. and Carter, C. B., J. Am. Ceram. Soc., Vol. 72, pp. 864-867 (1989).

24) Stumph, H. C., Russell, A. S., Newsome, J. W. and Tucker, C. M., Ind. Eng. Chem., Vol. 42, pp. 1398-1403 (1950).

25) Fujita, T., Kitajima, K., Taruta, S. and Takusagawa, N., Nippon Kagaku Kaishi, pp. 319-328 (1993) [in Japanese].

26) Fujita, T., Yamaguchi, T., Takusagawa, N. and Kitajima, K., J. Ceram. Soc. Japan, Vol. 106, pp. 1017-1022 (1998) [in Japanese].

27) Fujita, T., Yamaguchi, T., Takusagawa, N. and Kitajima, K., J. Ceram. Soc. Japan, Vol. 106, pp. 1242-1247 (1998) [in Japanese].

28) Fujita, T., Yamaguchi, T., Taruta, S. and Kitajima, K., J. Ceram. Soc. Japan, Vol. 107, pp. 353-358 (1999) [in Japanese].

29) Fujita, T., Yamaguchi, T., Taruta, S. and Kitajima, K., J. Ceram. Soc. Japan, Vol. 108, pp. 172-177 (2000) [in Japanese].

30) Yamaguchi, T., Echizen, M., Fujita, T., Taruta, S. and Kitajima, K., J. Ceram. Soc. Japan, Vol. 108, pp. 960-965 (2000).

31) Yamaguchi, T., Echizen, M., Fujita, T., Taruta, S. and Kitajima, K., J. Ceram. Soc. Japan, Vol. 110, pp. 954-958 (2002).

32) Yajima, Y., Hida, M., Taruta, S. and Kitajima, K., J. Ceram. Soc. Japan, Vol. 111, pp. 110-116 (2003) [in Japanese].

33) Yajima, Y., Hida, M., Taruta, S. and Kitajima, K., J. Ceram. Soc. Japan, Vol. 111, pp. 419-425 (2003) [in Japanese].

34) Yajima, Y., Yamaguchi, T., Taruta, S. and Kitajima, K., J. Ceram. Soc. Japan, Vol. 111, pp. 786-789 (2003). 